\title{
Heavy Metal Contamination of the Loučka River Water Ecosystem
}

\author{
T. VÍTEK, P. SPURNÝ, J. MAREŠ, A. ZIKOVÁ
}

Mendel University of Agriculture and Forestry, Department of Fishery and Hydrobiology, Brno, Czech Republic

Received May 15, 2006

Accepted September 5, 2006

\begin{abstract}
Vítek T., P. Spurný, J. Mareš, A. Ziková: Heavy Metal Contamination of the Loučka River Water Ecosystem. Acta Vet Brno 2007, 76:149-154.

Heavy metal contamination of the Loučka River water ecosystem was assessed in July 2005. We analyzed concentrations of T-Hg (total mercury), $\mathrm{Cd}, \mathrm{Pb}, \mathrm{Cr}, \mathrm{Cu}, \mathrm{Zn}$, and $\mathrm{Ni}$ in water, sediments, zoobenthos, and in the brown trout (Salmo trutta m. fario) muscle and liver tissues (a total of 28 individuals) at four sampling sites. The highest $\mathrm{Pb}$ and $\mathrm{Ni}$ concentrations (4.634 - 12.050 and 0.689 $-24.980 \mathrm{mg} \cdot \mathrm{kg}^{-1}$ ) were found in sediments. The zoobenthos was most contaminated by $\mathrm{Zn}$ and $\mathrm{Cu}$ $\left(0.556-1.505\right.$ and $\left.2.925-74.300 \mathrm{mg} \cdot \mathrm{kg}^{-1}\right)$. The heavy metal contamination of river water was highest in $\mathrm{Ni}$ and $\mathrm{Cr}\left(0.1-6.8\right.$ and $\left.0.5-10.0 \mathrm{mg} \cdot \mathrm{l}^{-1}\right)$. Concentrations of heavy metals in the brown trout muscle were following (in $\mathrm{mg} \cdot \mathrm{kg}^{-1}$ ): $\mathrm{Pb} 0.108 \pm 0.073-1.010 \pm 0.506, \mathrm{Cd} 0.003 \pm 0.002-$ $0.026 \pm 0.022, \mathrm{Zn} 3.956 \pm 0.371-5.801 \pm 1.718, \mathrm{Ni} 0.058 \pm 0.018-0.102 \pm 0.046, \mathrm{Cr} 0.028 \pm 0.005$ $-0.073 \pm 0.039, \mathrm{Cu} 0.329 \pm 0.079-0.437 \pm 0.064$ and $\mathrm{Hg} 0.065 \pm 0.008-0.106 \pm 0.047$. Statistical differences $(P<0.05)$ in the brown trout muscle were in $\mathrm{Pb}$ and $\mathrm{Zn}$. $\mathrm{Cd}, \mathrm{Cu}$ and $\mathrm{Zn}$ were markedly accumulated in the brown trout liver (concentrations $0.107 \pm 0.066-0.223 \pm 0.078,59.973$ $\pm 38.951-145.800 \pm 48.286$ and $\left.30.671 \pm 3.574-34.274 \pm 7.226 \mathrm{mg} \cdot \mathrm{kg}^{-1}\right)$. Humans of $60 \mathrm{~kg}$ body mass may consume $1.5 \mathrm{~kg}$ of brown trout muscle from the Loučka River weekly without any risk. Adverse influence of the Uniglas distillery on the Loučka River environment contamination by heavy metals was not confirmed.
\end{abstract}

Czech Republic, stream ecosystems, brown trout, mercury, lead

The contamination of the water ecosystems is a worldwide problem of great importance. In the Czech Republic we can consider the situation of water pollution as improving from year to year, but it is not optimal yet. Heavy metals do not have primary lethal effect on hydrobionts but they have long-term negative influences on them.

Heavy metals have negative impacts on ecological stability of water ecosystems because of long-term environmental chronic stress. They cause fish growth disturbances, reproduction failure, immunosupression (Stave and Robers on 1985), histopathological changes in fish skin, gills, liver and kidneys and skeleton deformations (Sloof 1982; Hinton and Laurén 1990). Exposure of fish to heavy metals can cause metallothionein synthesis in the liver, kidneys and gills, and these metals can thus infiltrate the fish body directly by this non-alimentary way (Hamilton and Mehrle 1986). In addition, copper and mercury slow down fish metabolism by gill damage and enormous mucus secretion (Rice 1990).

Over the last 15 years, the heavy metals monitoring in stream ecosystems and distribution of heavy metals in fish tissues of different fishes has been carried out in many countries (Olsvik et al. 2001 - Norway, brown trout; Falandysz et al. 2000 - different species, Vistula River, Poland; Albeke et al. 2001 - Colorado, brown trout; B ervoets and Blust 2003 - Belgium, gudgeon; Linde et al. 2004 - Spain, brown trout and eel; Allengyl and Martynov 1995 - 9 species, Pechora River, Russia). Spurný et al. (2002 - Jihlava River, chub) and Svobodová et al. (2004 - Tichá Orlice River and tributaries, brown trout) monitored the situation in Czech and Moravian rivers.

Address for correspondence:

Ing. Tomáš Vítek

Mendel University of Agriculture and Forestry

Department of Fishery and Hydrobiology

Zemědělská 1, 61300, Brno Cerná Pole

Czech Republic

GSM: +420732844296

e-mail: gabon@centrum.cz

http://www.vfu.cz/acta-vet/actavet.htm 
Beside the serious negative influence of heavy metal contamination on ichthyocenosis diversity and productivity, there is a possible health risk connected with regular consumption of heavy metal-contaminated fish in the long run, especially in sport fishermen and their families.

The Loučka River is divided into four fishing yards with salmonid stocking, which are of the ten most important in South Moravia. Beside low summer flow, ichthyocenosis prosperity is affected by water pollution. Over the last ten years there were several serious accidents resulting in mass fish death, that were mainly associated with Uniglas Company distillery industry near the Radešín village. Therefore field research was conducted, evaluating heavy metal contamination of the river water ecosystem.

\section{Materials and Methods}

The Loučka River is an important right-side tributary of the Svratka River with about $60 \mathrm{~km}$ of length and average annual flow of $2.0 \mathrm{~m}^{3} \cdot \mathrm{s}^{-1}$ at the mouth. Samples for laboratory analyses were taken from four sampling sites of the upper and middle course of the river (Loučka 4 and Loučka 2 fishing yards, Plate XIV, Fig. 1). Sampling sites were localized exactly by GPS Garmin iQue 3600 locator. Sampling sites 1 and 2 were situated upstream, whereas localities 3 and 4 downstream of the Uniglas Company distillery as the main supposed source of pollution. Due to the stream zonation, the localities 1,2 and 3 corresponded to the brown trout zone; locality 4 is a typical grayling zone. Following ichtyological parameters were used to characterize fish community: total abundance, total biomass, diversity index (according to Shannon and Weaver 1963) and equitability index (according to Sheldon 1969). The brown trout (Salmo trutta m. fario) was used as an ichthyoindicator. Seven individuals of this species from each sampling site were taken in July 2005. River water, riverbed sediment and macrozoobenthos were also sampled for further laboratory manipulation. Fish for heavy metal analyses were brought to the laboratory immediately after returning from the field researches. Dorsal muscle samples (in the amount of about $2 \mathrm{~g}$, without skin) and whole liver from each of the brown trout individual were taken carefully for individual assessment of heavy metal concentrations. These tissue samples were kept in a freezer at a temperature of $-18{ }^{\circ} \mathrm{C}$ together with the water, sediment and zoobenthos samples until further analyses. To determine the age of the brown trout, $5-8$ scales were sampled from each fish.

The concentration of total mercury $(\mathrm{T}-\mathrm{Hg})$, cadmium $(\mathrm{Cd})$, lead $(\mathrm{Pb})$, chromium $(\mathrm{Cr})$, copper $(\mathrm{Cu}), \mathrm{zinc}(\mathrm{Zn})$, and nickel (Ni) was analyzed after dry mineralizing using the Czech mineralizing equipment APION. Methods are described precisely by Spurný et al. (2002). Mercury was analyzed directly on the AMA 254 apparatus. Remaining heavy metals were detected by the AAS method on the SPECTR AA-30 apparatus with electro-thermal atomizer GTA-96 (in the case of $\mathrm{Cd}, \mathrm{Pb}, \mathrm{Cr}$ and $\mathrm{Ni}$ ). Concentration of $\mathrm{Cu}$ and $\mathrm{Zn}$ was assessed using the method of flame AAS on the AA3000 apparatus. For verification standards KS 1014 and KS 1015 were used from UKZUZ Brno.

The results were statistically compared using software Unistat 5.1 (ANOVA, test of Scheffe).

\section{Results and Discussion}

Heavy metal concentration in water, sediments and in macrozoobenthos of the Loučka River is given in Table 1. The highest concentration of lead, cadmium, zinc and mercury in sediments was detected in locality $2\left(12.050,0.303,75.100\right.$ and $\left.0.092 \mathrm{mg} \cdot \mathrm{kg}^{-1}\right)$. Markedly higher nickel and chromium concentrations were found in sediments of locality 4 (24.980 and $\left.36.196 \mathrm{mg} \cdot \mathrm{kg}^{-1}\right)$ and the highest copper concentration was detected in locality $1\left(8.200 \mathrm{mg} \cdot \mathrm{kg}^{-1}\right)$. Spurný et al. (2002) found in sediments of the Jihlava River below Třebíč higher concentrations of cadmium and zinc $\left(0.638\right.$ and $\left.102.840 \mathrm{mg} \cdot \mathrm{kg}^{-1}\right)$, similar concentrations of mercury, chromium and copper $\left(0.108,15.438\right.$ and $\left.12.974 \mathrm{mg} \cdot \mathrm{kg}^{-1}\right)$ and lower concentrations of lead and nickel (18.013 and $6.390 \mathrm{mg} \cdot \mathrm{kg}^{-1}$ ) compared to the Loučka River sediments. In zoobenthos samples the highest concentration of zinc and nickel was in locality 2 (67.300 and $\left.1.505 \mathrm{mg} \cdot \mathrm{kg}^{-1}\right)$, locality 1 showed the highest chromium, copper and mercury levels $(3.832$, $\left.74.300,0.030 \mathrm{mg} \cdot \mathrm{kg}^{-1}\right)$, the highest contamination by lead was found in locality $3(0.865$ $\left.\mathrm{mg} \cdot \mathrm{kg}^{-1}\right)$ and by cadmium in locality $4\left(0.255 \mathrm{mg} \cdot \mathrm{kg}^{-1}\right)$. Heavy metal contamination of zoobenthos in the Jihlava River (Spurný et al. 2002) is similar (maximal concentrations in $\mathrm{mg} \cdot \mathrm{kg}^{-1}$ are for $\mathrm{Hg} 0.054$, for $\mathrm{Cd} 0.126$, for $\mathrm{Cr} 1.595$, for $\mathrm{Cu} 5.198$, for $\mathrm{Zn} 34.120$ and for $\mathrm{Ni}$ 0.942 ) except for lead (in the Jihlava River concentration of $1.920 \mathrm{mg} \cdot \mathrm{kg}^{-1}$ was detected, which is about two times higher than the maximum in the Loučka River). Heavy metal 
Table 1. The Loučka River ecosystem contamination by heavy metals at four sampling sites in July $2005\left(\mathrm{mg} \cdot \mathrm{kg}^{-1}\right)$

\begin{tabular}{|l|c|c|c|c|c|c|c|c|}
\hline Specimen & Site & $\mathrm{Pb}$ & $\mathrm{Cd}$ & $\mathrm{Zn}$ & $\mathrm{Ni}$ & $\mathrm{Cr}$ & $\mathrm{Cu}$ & $\mathrm{Hg}$ \\
\hline \multirow{4}{*}{ Sediments } & 1 & 11.8900 & 0.2450 & 15.6090 & 0.6890 & 9.3840 & 80.2000 & 0.0448 \\
\cline { 2 - 9 } & 2 & 12.0500 & 0.3030 & 75.1000 & 13.1470 & 14.0000 & 19.9400 & 0.0921 \\
\cline { 2 - 9 } & 3 & 9.1400 & 0.1650 & 44.0000 & 16.3640 & 19.2400 & 6.1620 & 0.0411 \\
\cline { 2 - 9 } & 4 & 4.6340 & 0.0760 & 0.2078 & 24.9800 & 36.1960 & 11.2600 & 0.2078 \\
\hline \multirow{4}{*}{ Wenthos } & 1 & 0.8160 & 0.0340 & 2.0240 & 0.5560 & 3.8320 & 74.3000 & 0.0303 \\
\cline { 2 - 9 } & 2 & 0.3270 & 0.1000 & 67.3000 & 1.5050 & 0.5950 & 4.8000 & 0.0237 \\
\cline { 2 - 9 } & 3 & 0.8650 & 0.0320 & 43.0000 & 0.6540 & 0.1760 & 2.9250 & 0.0157 \\
\cline { 2 - 9 } & 4 & 0.2360 & 0.2550 & 0.0197 & 1.0610 & 0.5270 & 4.5000 & 0.0197 \\
\hline \multirow{3}{*}{ Water } & 1 & 0.0016 & 0.0001 & 0.0110 & 0.0068 & 0.0100 & 0.0200 & 0.0004 \\
\cline { 2 - 9 } & 2 & 0.0025 & 0.0002 & 0.0100 & 0.0005 & 0.0006 & 0.0110 & 0.0002 \\
\cline { 2 - 9 } & 3 & 0.0016 & 0.0008 & 0.0050 & 0.0002 & 0.0004 & 0.0090 & 0.0001 \\
\cline { 2 - 9 } & 4 & 0.0020 & 0.0002 & 0.0007 & 0.0001 & 0.0005 & 0.0020 & 0.0007 \\
\hline
\end{tabular}

contamination of the Loučka River water was similar at all the sampling sites, except for a higher concentration of nickel and chromium in locality $2\left(6.8\right.$ and $\left.10.0 \mathrm{mg} \cdot \mathrm{l}^{-1}\right)$. Jihlava River is about a five times bigger stream than Loučka and flows through big towns (such as Jihlava with about 50000 and Třebíč with 35000 inhabitants); therefore contamination of the Loučka River water ecosystem by heavy metals can be considered as rather high.

Table 2. Basic ichthyologic parameters of the Loučka River fish community at four sampling sites in July 2005

\begin{tabular}{|c|c|c|c|c|}
\hline Sampling site & $\begin{array}{c}\text { Abundance } \\
\left(\text { indiv } \cdot \mathrm{ha}^{-1}\right)\end{array}$ & $\begin{array}{c}\text { Biomass } \\
\left(\mathrm{kg} \cdot \mathrm{ha}^{-1}\right)\end{array}$ & $\begin{array}{c}\text { Diversity index } \\
\left(\mathrm{H}^{\prime}\right)\end{array}$ & $\begin{array}{c}\text { Equitability } \\
\text { index (E) }\end{array}$ \\
\hline 1 & 3241 & 231.58 & 1.612 & 0.694 \\
\hline 2 & 635 & 109.73 & 1.325 & 0.836 \\
\hline 3 & 387 & 28.00 & 1.087 & 0.686 \\
\hline 4 & 1635 & 74.07 & 2.841 & 0.896 \\
\hline
\end{tabular}

Main characteristics of the fish community in the analyzed sector of the Loučka River are given in Table 2 . The highest fish concentration and biomass was detected in locality 1 (3 $241 \mathrm{fish} \cdot \mathrm{ha}^{-1}$ and $231.58 \mathrm{~kg} \cdot \mathrm{ha}^{-1}$ ). It is the highest upstream locality, and the proximity of a trout-rearing brook can result in higher values. The highest diversity and equitability was in the furthest downstream situated locality $4\left(\mathrm{H}^{\prime}=2.841\right.$ and $\left.\mathrm{E}=0.896\right)$.

The results of heavy metal concentration analyzed in the brown trout muscle and liver are presented in Tables 3 and 4. The concentration of copper in the brown trout liver in the

Table 3. Heavy metal concentration (mean $\pm \mathrm{SD}, \mathrm{n}=7$ ) in the brown trout (S. trutta $\mathrm{m}$. fario) muscle from the Loučka River (in $\mathrm{mg} \cdot \mathrm{kg}^{-1}$ of wet matter)

\begin{tabular}{|c|c|c|c|c|}
\hline Sampling site & $\begin{array}{c}1 \text { age } 2+-3+ \\
\text { average 3+ }\end{array}$ & $\begin{array}{c}\text { 2 age 2+-3+ } \\
\text { average 3+ }\end{array}$ & $\begin{array}{c}\text { 3 age 2+-3+ } \\
\text { average 2+ }\end{array}$ & $\begin{array}{c}4 \text { age 2+-3+ } \\
\text { average 2+ }\end{array}$ \\
\hline $\mathrm{Pb}$ & $0.390 \pm 0.311^{\mathrm{a}}$ & $0.108 \pm 0.073^{\mathrm{a}}$ & $0.281 \pm 0.322^{\mathrm{a}}$ & $1.010 \pm 0.506^{\mathrm{b}}$ \\
\hline $\mathrm{Cd}$ & $0.023 \pm 0.028$ & $0.007 \pm 0.004$ & $0.003 \pm 0.002$ & $0.026 \pm 0.022$ \\
\hline $\mathrm{Zn}$ & $5.531 \pm 0.530$ & $4.631 \pm 0.639$ & $5.801 \pm 1.718^{\mathrm{a}}$ & $3.956 \pm 0.371^{\mathrm{b}}$ \\
\hline $\mathrm{Ni}$ & $0.058 \pm 0.018$ & $0.080 \pm 0.043$ & $0.079 \pm 0.020$ & $0.102 \pm 0.046$ \\
\hline $\mathrm{Cr}$ & $0.041 \pm 0.023$ & $0.059 \pm 0.030$ & $0.073 \pm 0.039$ & $0.028 \pm 0.005$ \\
\hline $\mathrm{Cu}$ & $0.399 \pm 0.163$ & $0.437 \pm 0.064$ & $0.329 \pm 0.079$ & $0.386 \pm 0.043$ \\
\hline $\mathrm{Hg}$ & $0.065 \pm 0.008$ & $0.089 \pm 0.017$ & $0.088 \pm 0.013$ & $0.106 \pm 0.047$ \\
\hline
\end{tabular}

Statistical differences are indexed by letters, same letters for homogenous groups 
Table 4. Heavy metal concentration (mean $\pm \mathrm{SD}, \mathrm{n}=7$ ) in the brown trout (S. trutta $\mathrm{m}$. fario) liver Loučka from the River (in $\mathrm{mg} \cdot \mathrm{kg}^{-1}$ of wet matter)

\begin{tabular}{|c|c|c|c|c|}
\hline Sampling site & 1 & 2 & 3 & 4 \\
\hline $\mathrm{Pb}$ & $0.347 \pm 0.184^{\mathrm{a}}$ & $0.073 \pm 0.030 \mathrm{a}$ & $0.374 \pm 0.176^{\mathrm{a}}$ & $1.721 \pm 1.238^{\mathrm{b}}$ \\
\hline $\mathrm{Cd}$ & $0.107 \pm 0.066$ & $0.126 \pm 0.066$ & $0.202 \pm 0.064$ & $0.223 \pm 0.078$ \\
\hline $\mathrm{Zn}$ & $30.671 \pm 3.574$ & $31.131 \pm 6.538$ & $34.274 \pm 7.226$ & $32.533 \pm 2.825$ \\
\hline $\mathrm{Ni}$ & $0.060 \pm 0.017^{\mathrm{a}}$ & $0.079 \pm 0.074^{\mathrm{a}}$ & $0.099 \pm 0.068^{\mathrm{a}}$ & $0.328 \pm 0.117^{\mathrm{b}}$ \\
\hline $\mathrm{Cr}$ & $0.068 \pm 0.024$ & $0.035 \pm 0.021$ & $0.060 \pm 0.040$ & $0.067 \pm 0.047$ \\
\hline $\mathrm{Cu}$ & $59.973 \pm 38.951^{\mathrm{a}}$ & $51.709 \pm 24.749^{\mathrm{a}}$ & $92.510 \pm 54.454$ & $145.800 \pm 48.286^{\mathrm{b}}$ \\
\hline $\mathrm{Hg}$ & $0.143 \pm 0.024$ & $0.147 \pm 0.038$ & $0.123 \pm 0.019$ & $0.159 \pm 0.056$ \\
\hline
\end{tabular}

Statistical differences are indexed by letters, same letters for homogenous groups

Loučka River is about five times higher compared to Piguena River in northern Spain (Linde et al. 1999). As Svobodová et al. (2004) report, in the upper reaches of the Tichá Orlice River brown trout muscle contamination by cadmium was lower (maximum 0.0073 as opposed to $0.026 \mathrm{mg} \cdot \mathrm{kg}^{-1}$ ) and higher by nickel (maximum 0.146 against $0.102 \mathrm{mg} \cdot \mathrm{kg}^{-1}$ ), than in the Loučka River. In the case of copper, zinc and chromium the values were similar $(0.343$, 4.53 and 0.081 as opposed to $0.437,5.801$ and $0.073 \mathrm{mg} \cdot \mathrm{kg}^{-1}$ ).

Presently, in the Czech Republic the FAO/WHO limits are important (Table 5). The maximum tolerable daily or weekly human intakes of brown trout muscle from the Loučka River are included in Table 5 (values for a human consumer of $60 \mathrm{~kg}$ body mass). The maximum concentration of all the localities for each heavy metal was used there. Apparently, the most limiting heavy metal is lead. People can eat $1.5 \mathrm{~kg}$ of brown trout muscle weekly without any risk. Although the concentration of lead in the zoobenthos in the Jihlava River is higher, the chub muscle contamination by lead is lower (mean value below Třebíč $0.636 \mathrm{mg} \cdot \mathrm{kg}^{-1}$; S purný et al. 2002). Other heavy metals are of no concern for human consumption. As Houserová et al. (2006) report, concentration of total mercury in the chub muscle at the lower reach of the Loučka River was also lower than in our research.

Table 5. Maximal brown trout muscle intake from Loučka River according to FAO/WHO limits (in $\mathrm{kg} \cdot 60 \mathrm{~kg}^{-1}$ body mass of human consumer)

\begin{tabular}{|c|c|c|c|c|c|c|c|}
\hline metal & $\mathrm{Pb}$ & $\mathrm{Cd}$ & $\mathrm{Zn}$ & $\mathrm{Ni}$ & $\mathrm{Cr}$ & $\mathrm{Cu}$ & $\mathrm{Hg}$ \\
\hline $\begin{array}{c}\text { Limit } \\
\left(\mu \mathrm{g} \cdot \mathrm{kg}^{-1}\right)\end{array}$ & $\begin{array}{c}25 \\
\text { PTWI }\end{array}$ & $\begin{array}{c}7 \\
\text { PTWI }\end{array}$ & $\begin{array}{c}1000 \\
\text { PMTDI }\end{array}$ & - & - & 500 & 5 \\
intake & 1.5 & 16.2 & 10.3 & - & - & 68.6 & 2.8 \\
\hline
\end{tabular}

PTWI-provisional tolerated weekly intake, PMTDI-provisional maximum tolerable daily intake

When we compare heavy metal concentrations in the brown trout muscle to its liver, a strong increase of cadmium, zinc and copper is obvious. These metals are bioaccumulated in the liver for detoxication. There is a risk of metallothionein synthesis in the fish body, which can cause another increase of these metals concentration in fish body as Hog strand et al. (1991) describe in perch, Olsvik et al. (2001) in brown trout in Norwegian rivers and Linde et al. (1999 and 2001) in brown trout in Spain. As our ichthyological research in the Loučka River shows, the occurrence of individuals older than 3 years is rare, and the analyzed fish were purely in the age of $2+$ and $3+$ (Table 3 ).

Comparing heavy metal contamination of the brown trout muscle from four sampling sites of the Loučka River, statistically significant differences were found between locality 4 and the other ones in lead concentration, when the value in locality 4 was markedly higher. 
Significantly lower concentration of zinc in locality 4 compared to locality 3 was also found (Table 3).

In the case of brown trout liver contamination by heavy metals, the statistical comparison also showed several differences. At locality 4, the concentration of lead (corresponding to concentration in the muscle) and the concentration of nickel significantly exceeds the remaining sampling sites. Another significant difference was in copper at locality 4 (a higher value) compared to localities 1 and 2 (Table 4). Because no statistical differences were found between localities 2 and 3 in the heavy metal concentration of brown trout tissues, we can exclude the adverse influence of the Uniglas distillery on the Loučka River environment in relation to contamination by heavy metals.

If we consider brown trout as an indicator of heavy metal contamination in the water environment (Linde et al. 1998), the water, sediment and zoobenthos in locality 4 should be the most contaminated by lead, but the reality is different. It may be due to feeding migrations or a consequence of brown trout stocking (this species is stocked yearly at the age of $1+$ and $2+$ ). The analyzed fish thus may not belong to the original population, originating from a different stream, or they may have moved upstream from probably more contaminated lower parts of this river.

\section{Zatížení vodního ekosystému řeky Loučky těžkými kovy}

V červenci 2005 bylo provedeno sledování zatížení vodního ekosystému řeky Loučky těžkými kovy. Analyzovali jsme koncentraci T-Hg (celková rtut'), $\mathrm{Cd}, \mathrm{Pb}, \mathrm{Cr}, \mathrm{Cu}, \mathrm{Zn}$, a Ni ve vodě, sedimentu a bentosu a dále ve svalové a jaterní tkáni pstruha obecného f. potoční (Salmo trutta m. fario; celkem 28 jedinců), a to na čtyřech lokalitách. Nejvyšší koncentrace v sedimentu byla zjištěna u Pb a Ni (4,634 - 12,050 a 0,689 - 24, $\left.980 \mathrm{mg} \cdot \mathrm{kg}^{-1}\right)$. Zoobentos byl nejvíce kontaminován $\mathrm{Zn}$ a Cu $\left(0,556\right.$ - 1,505 a 2,925 - 74,300 mg. $\left.\mathrm{kg}^{-1}\right)$. Zatížení říční vody těžkými kovy bylo nejvyšší u Ni a Cr $\left(0,1-6,8\right.$ a 0,5 - 10,0 mg $\left.\cdot \mathrm{l}^{-1}\right)$. Koncentrace těžkých kovů ve svalovině pstruha potočního byly následující (v mg.kg-1): $\mathrm{Pb} 0,108 \pm 0,073-1,010$

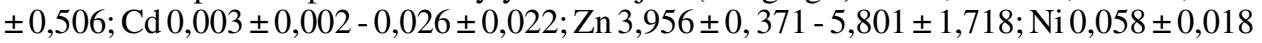
$-0,102 \pm 0,046 ;$ Cr 0, $028 \pm 0,005-0,073 \pm 0,039 ; \mathrm{Cu} 0,329 \pm 0,079-0,437 \pm 0,064$ a Hg $0,065 \pm 0,008-0,106 \pm 0,047$. Byly zjištěny statistické rozdíly $(P<0.05)$ v obsahu $\mathrm{Pb}$ a Zn ve svalovině pstruha obecného. $\mathrm{Cd}, \mathrm{Cu}$ a $\mathrm{Zn}$ jsou výrazně akumulovány v játrech pstruha obecného (koncentrace 0,107 \pm 0,066 - 0,223 \pm 0,078; 59,973 $\pm 38,951-145,800 \pm 48,286$ a 30,671 $\left.\pm 3,574-34,274 \pm 7,226 \mathrm{mg} \cdot \mathrm{kg}^{-1}\right)$. Člověk vážící $60 \mathrm{~kg}$ může bez jakéhokoliv rizika zkonzumovat $1,5 \mathrm{~kg}$ svaloviny pstruha obecného týdně. Negativní vliv lihovaru firmy Uniglas na zatížení ekosystému řeky Loučky těžkými kovy prokázán nebyl.

\section{Acknowledgements}

This research was supported by the Ministry of Agriculture of the Czech Republic (project QF 3028 NAZV) and by Ministry of Education, Youth and Physical Training of the Czech Republic (project 1528/G4 FRVS).

\section{References}

ALBEKE SE, WOODLING JD, WIDMER AM 2001: Use of regional standard weight (Ws) equations to assess body condition of brown trout (Salmo trutta) from metal-contaminated streams. J Freshwater Ecol 16(4): 501-508

ALLENGIL SM, MARTYMOV VG 1995: Heavy-metal burdens in 9 species of fresh-water and anadromous fish from the Pechora River, northern Russia. Sci Total Envir 161: 653-659

BERVOETS L, BLUST R 2003: Metal concentrations in water, sediment and gudgeon (Gobio gobio) from a pollution gradient: relationship with fish condition factor. Environ Pollut 126: 9-19

FALANDYSZ J, CHWIR A, WYRZYKOWSKA B 2000: Total mercury contamination of some fish species in the Firth of Vistula and the Lower Vistula River, Poland. Polish J Environ Stud 9: 335-339

HAMILTON SJ, MEHRLE PM 1986: Metallothionein in fish: review of its importance in assessing stress from metal contaminants. Trans Amer Fish Soc 115: 596-609 
HINTON DE, LAURÉN DJ 1990: Integrative histopathological approaches to detecting effects of environmental stressors on fishes. Biological indicators of stress in fish 8. American Fisheries Society Symposium, Maryland, pp. 51-66

HOGSTRAND C, LITHNER G, HAUX C 1991: The importance of metallothionein for the accumulation of copper, zinc and cadmium in environmentally exposed perch, Perca fluviatilis. Pharmacol Toxicol 68: 492-501

HOUSEROVÁ P, KUBÁŇ V, SPURNÝ P, HABARTA P 2006: Determination of total mercury and mercury species in fish and aquatic ecosystems of Moravian rivers. Vet Med - Czech 51: 101-110

LINDE AR, SANCHEZ-GALAN S, GARCIA-VAZQUEZ E 2004: Heavy metal contamination of European eel (Anguilla anguilla) and brown trout (Salmo trutta) caught in wild ecosystems in Spain. J Food Protect 67: 2332-2336

LINDE AR, SANCHEZ-GALAN S, IZQUIERDO JI, ARRIBAS P, MARANON E, GARCIA-VASQUEZE 1998: Brown trout as biomonitor of heavy metal pollution: Effect of age on the reliability of the assessment. Ecotoxicol Environ Safety 40: 120-125

LINDE AR, SANCHEZ-GALAN S, KLEIN D, GARCIA-VAZQUEZ E, SUMMER KH 1999: Metallothionein and heavy metals in brown trout (Salmo trutta) and European eel (Anguilla anguilla): A comparative study. Ecotoxicol Environ Safety 44: 168-173

LINDE AR, SANCHES-GALAN S, VALLES-MOTTA P, GARCIA-VAZQUEZ E 2001: Metallothionein as bioindicator of freshwater metal pollution: European eel and brown trout. Ecotoxicol Environ Safety 49: 60-63

OLSVIK PA 2001: Metal accumulation and metallothionein in brown trout, Salmo trutta, from two Norwegian rivers differently contaminated with $\mathrm{Cd}, \mathrm{Cu}$ and $\mathrm{Zn}$. Comp Biochem Physiol PT C 128: 189-201

RICE JA 1990: Bioenergetics modeling approaches to evaluation of stress in fish. Biological indicators of stress in fish 8. American Fisheries Society symposium, Maryland, pp. 80-92

SHANNON CE, WEAVER V 1963: The mathematical theory of communities. Univ Illinois Press, Urbana

SHELDON AL 1969: Equitability indices: dependence on the species count. Ecology 50: 466-467

SLOOF W 1982: Skeletal anomalies in fish from polluted surface waters. Aquat Toxicol 2: 157-173

SPURNÝ P, MAREŠ J, HEDBÁVNÝ J, SUKOP I 2002: Heavy metal distribution in the ecosystems of the upper course of the Jihlava River. Czech J Anim Sci 47: 160-167

STAVE, JW, ROBERSON, BS 1985: Hydrocortisone suppresses the chemiluminescent response of stripped bass phagocytes. Develop Comp Immunol 9: 77-84

SVOBODOVÁ Z, ČELECHOVSKÁ O, ŽLÁBEK V 2004: Assessment of metal contamination in the upper reaches of the Tichá Orlice River. Czech J Anim Sci 49: 458-464 


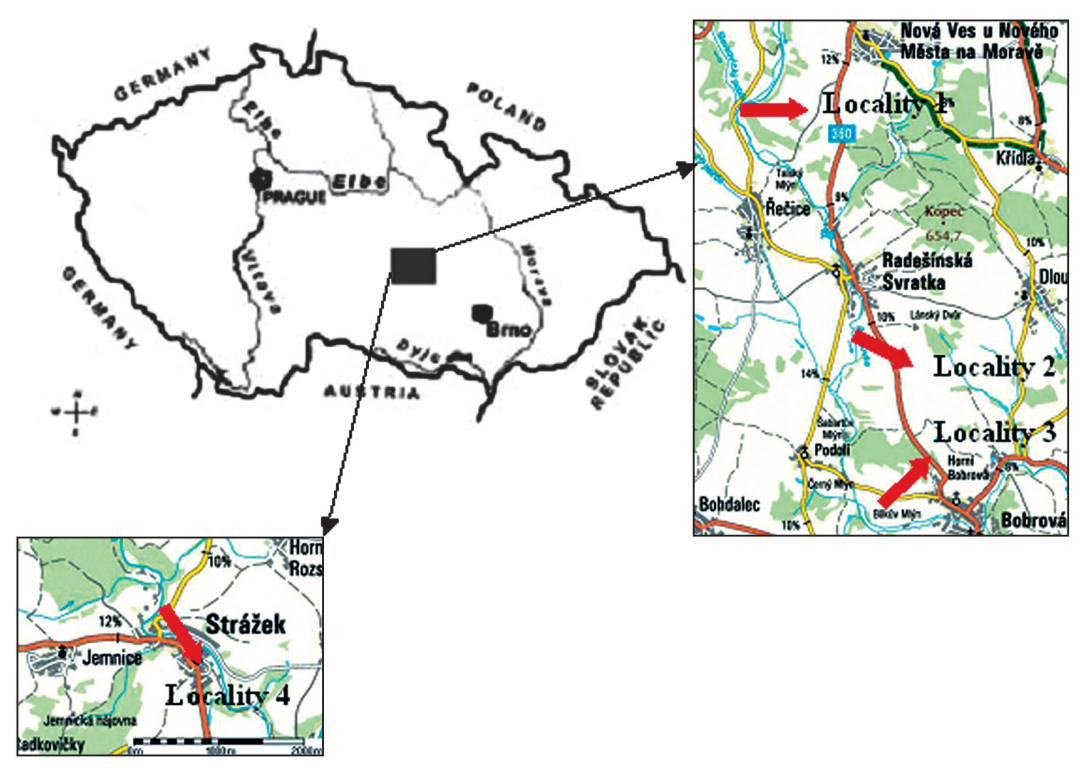

Fig. 1. Location of the Loučka River sampling area 